\title{
Evaluation of coffee intercropped with rice and plantain at early stage of field establishment in Nigeria
}

\author{
Amos Olatunde Famaye*, Gerald O. Iremiren, Kayode Olufemi Ayegboyin, \\ Kayode Babatunde Adejobi \\ Cocoa Research Institute of Nigeria, Ibadan, Nigeria; *Corresponding Author: tunmos2010@yahoo.com
}

Received 6 January 2012; revised 23 February 2012; accepted 14 March 2012

\section{ABSTRACT}

An intercropping experiment involving coffee (sole), coffee/rice, coffee/plantain and coffeel rice/plantain was carried out between 2007 and 2008 at the Cocoa Research Institute of Nigeria (CRIN) Uhonmora Substation, Edo State situated in a derived Guinea Savanna agro-ecological zone of Nigeria. The experiment was a Randomized Complete Block Design (RCBD) with above mentioned treatment and replicated three times. The spacing used for coffee and plantain was 3 m apart respectively while rice was sown $30 \mathrm{~cm}$ apart. Morphological parameters such as plant height, stem girth, leaf area and canopy score were taken on coffee monthly while the survival count were taken after two months of field establishment. Yields of the component crops were also collected at maturity. Data collected were subjected to statistical analysis of variance and LSD used to separate the means that were significant. Result obtained showed $98 \%$ survival without any significant difference among the treatments. On vegetative growth, coffee/rice and coffee/plantain were significantly higher ( $P$ $<0.05$ ) than coffee sole and coffee/rice/plantain in plant girth and leaf area but not significantly higher in all the months. Plant height however did not follow the same trend as height in coffee sole was slightly higher than coffee/rice. However, the difference was not significant. But coffee/plantain was still significantly higher $(P<$ 0.05) than coffee/rice/plantain. The least was recorded in coffee/rice/plantain intercrop. Grain and bunch yields from rice and plantain respectively in the intercrops compare favourable well to what obtain from coffee sole. From the result obtained, it could be concluded that there was no deleterious effect on growth when rice and plantain were intercropped with coffee. Therefore coffee/rice and coffee/plantain intercropped with better performance could be recommended to coffee farmers in Nigeria rather than sole planting of coffee.

Keywords: Evaluation; Coffee; Rice; Plantain; Intercrop

\section{INTRODUCTION}

Farming system involves harnessing resources as dictated by the environment. Monoculture, to which our attention had been diverted by our colonial master in the past, is not suitable to our culture. Therefore, efforts are now being geared to ensure that crop production in Nigeria either by Government organs or private farmers is based on multiple cropping systems so as to benefit from the advantages derivable from the practice. According to [1]; as well as [2]. Such benefits include higher yield returns, insurance against crop failure, more efficient use of available nutrients, improved environmental factors, reduction in weed pests and diseases incidence, and efficient use of labour.

Intercropping is the practice of planting two or more crops simultaneously on the same piece of land and is mostly practiced among the various forms of multiple cropping. Intercropping had been reported to increase crop diversity, biological stability of the ecosystem and labour efficiency [3]. Oil palm, coffee, cocoa and kola have been successfully intercropped with other tree and arable crops [4-6]. Intercropping in coffee carried out to provide foods and incomes to farmers in Nigeria is usually done at early stage of field establishment before they close canopy and during rehabilitation of the old farms [7]. Suitable intercropping system have been achieved in coffee with arable crops like cassava, maize, cocoyam, 
sweet potato, okra and pepper $[6,8,9]$ but none yet on rice. Despite the various advantages derivable from rice as one of the choice staple food eaten by all and sundry in Nigeria, efforts have not been taken to intercrop it with coffee. Rice had been reported to be successfully grown as cover crop in young coffee, cacao, citrus and rubber trees in Japan, Brazil, Cote'Divore and Thailand [10]. Following the world food crisis in which Nigeria experienced high cost in rice as a result of short supply from exporting nations few years ago, it now becomes imperative for coffee farmers to intercrop with rice. Apart from food, they will equally get adequate income to improve their livelihood from rice at the early stage of field establishment when coffee has not started bearing berry. Therefore, the objective of this study is to evaluate the performance of coffee when intercropped with rice and plantain at early stage of field establishment.

\section{MATERIALS AND METHODS}

This study was carried out in Cocoa Research Institute of Nigeria (CRIN), Uhonmora Substation $6^{\circ} 50 ' \mathrm{~N}, 5^{\circ} 50^{\prime} \mathrm{E}$ ) (utilsol) with altitude of about $140 \mathrm{M}$ above sea level between 2007 and 2008. Uhonmora is located in the derived savanna zone of Nigeria. The ripe berries of Coffea canephora (robusta coffee) were obtained from the substation's plot and the seedlings were raised in the nursery. Plantain suckers were also obtained from one of the Substation's plot, while local rice variety was obtained from Ekpoma market, a community noted for Ekpoma local rice production in Edo State, Nigeria.

Land preparation was done and all trash and trees were removed. The experimental design was randomized complete block (RCBD) with four treatments comprising of coffee sole, coffee/rice, coffee/plantain and coffee/rice/ plantain replicated three times. Parameters considered were physical and chemical properties of the soil at the beginning of the experiment, survival count, as well as plant height, stem girth and leaf area. Yield of rice (grain) and plantain (bunch) were also evaluated. Data collected were subjected to statistical analysis of variance and LSD was used to separate the means that were significant.

\section{RESULTS AND DISCUSSION}

The result obtained on the physical and chemical properties of the study location is shown in Table 1. The soil $\mathrm{pH}$ of 5.3 was adequate for coffee. On survival count carried out after the first dry season of transplanting over $98 \%$ was obtained in all the treatments without any significant difference $(\mathrm{P}<0.05)$ among them. Tables 2, 3 and $\mathbf{4}$ show the plant height, stem diameter and leaf area of coffee in the different intercrops. The plant height was highest in coffee/plantain and closely followed by coffee sole than other treatments while the least value recorded was in coffee/rice/plantain. On stem girth and leaf area, the highest was coffee/plantain followed by coffee/rice which was a change in trend compared with the plant height of coffee sole. There was no significant difference between coffee/rice and coffee/plantain intercrops. However, there were significant difference $(\mathrm{P}<0.05)$ between them and coffee/rice/plantain. The high growth performance recorded in these two intercrops indicated

Table 1. Soil physical and chemical properties of the experimental site at the beginning of the experiment.

\begin{tabular}{cc}
\hline Soil Properties & Uhonmora \\
\hline pH $\left(\mathrm{H}_{2} \mathrm{O}\right)$ & 5.3 \\
\% Organic carbon & 0.83 \\
\% Total nitrogen & 0.08 \\
Available P (mg/kg) soil & 7.16 \\
Exchangeable K (c·mol $/ \mathrm{kg})$ soil & 0.06 \\
Exchangeable Ca (c·mol $/ \mathrm{kg})$ soil & 2.70 \\
Exchangeable Mg (c·mol $/ \mathrm{kg})$ soil & 0.05 \\
Exchangeable Na (c·mol $/ \mathrm{kg})$ soil & 0.02 \\
\% Sand & 78.6 \\
\% Silt & 9.3 \\
\% Clay & 12.1 \\
Soil classification & Ultisol \\
\hline
\end{tabular}

Table 2. Mean plant height (cm) of coffee intercropped with rice and plantain, months after transplanting (Sept. 2007-Sept. 2008).

\begin{tabular}{|c|c|c|c|c|c|c|c|c|c|c|c|c|c|}
\hline Treatment & $\mathrm{S}$ & $\mathrm{O}$ & $\mathrm{N}$ & $\mathrm{D}$ & $\mathrm{J}$ & $\mathrm{F}$ & M & A & M & $\mathrm{J}$ & $\mathrm{J}$ & A & $\mathrm{S}$ \\
\hline Coffee sole & 24.8 & 28.4 & 36.4 & 39.4 & 44.3 & 49.4 & 50.2 & 53.1 & 55.2 & 56.6 & 58.3 & 60.9 & 62.5 \\
\hline Coffee/rice & 20.6 & 26.9 & 32.6 & 36.5 & 40.7 & 45.3 & 47.9 & 50.8 & 52.0 & 54.7 & 57.9 & 60.7 & 63.6 \\
\hline Coffee/plantain & 24.5 & 27.6 & 36.2 & 39.7 & 45.9 & 50.5 & 52.5 & 57.3 & 60.7 & 62.9 & 65.4 & 67.5 & 69.8 \\
\hline Coffee/rice/plantain & 19.6 & 24.9 & 30.2 & 32.8 & 34.7 & 35.4 & 36.9 & 38.8 & 41.7 & 42.4 & 43.6 & 43.9 & 44.5 \\
\hline Mean & 22.4 & 27.0 & 33.6 & 37.1 & 41.4 & 45.2 & 46.9 & 50 & 52.4 & 1.15 & 56.3 & 58.3 & 60.1 \\
\hline $\operatorname{LSD}(\mathrm{P}=0.05)$ & 3.67 & 2.06 & 3.83 & 4.42 & 6.84 & 9.47 & 9.52 & 10.96 & 11.00 & 11.82 & 12.59 & 13.88 & 15.0 \\
\hline
\end{tabular}


Table 3. Mean stem girth (cm) of coffee intercropped with rice and plantain, months after transplanting (Sept. 2007-Sept. 2008).

\begin{tabular}{cccccccccccccc}
\hline Treatment & $\mathrm{S}$ & $\mathrm{O}$ & $\mathrm{N}$ & $\mathrm{D}$ & $\mathrm{J}$ & $\mathrm{F}$ & $\mathrm{M}$ & $\mathrm{A}$ & $\mathrm{M}$ & $\mathrm{J}$ & $\mathrm{J}$ & $\mathrm{A}$ & $\mathrm{S}$ \\
\hline Coffee sole & 0.55 & 0.67 & 0.77 & 0.85 & 0.93 & 0.97 & 0.99 & 1.04 & 1.08 & 1.1 & 1.1 & 1.2 & 1.2 \\
Coffee/rice & 0.48 & 0.59 & 0.72 & 0.83 & 0.91 & 0.99 & 1.05 & 1.09 & 1.12 & 1.19 & 1.20 & 1.23 & 1.28 \\
Coffee/plantain & 0.50 & 0.63 & 0.83 & 0.90 & 1.05 & 1.09 & 1.14 & 1.18 & 1.23 & 1.29 & 1.36 & 1.40 & 1.51 \\
Coffee/rice/plantain & 0.42 & 0.58 & 0.63 & 0.77 & 0.80 & 0.84 & 0.89 & 0.92 & 0.97 & 1.01 & 1.03 & 1.06 & 1.10 \\
Mean & 0.49 & 0.62 & 0.74 & 0.84 & 0.92 & 0.97 & 1.02 & 1.06 & 11 & 1.15 & 1.10 & 1.23 & 1.28 \\
LSD (P = 0.05) & 0.74 & 0.05 & 0.12 & 0.07 & 0.14 & 0.14 & 0.14 & 0.15 & 0.15 & 0.16 & 0.19 & 0.19 & 0.23 \\
\hline
\end{tabular}

Table 4. Mean leaf area (cm) of coffee intercropped with rice plantain, months after transplanting (Sept. 2007-Sept. 2008).

\begin{tabular}{|c|c|c|c|c|c|c|c|c|c|c|}
\hline Treatment & $\mathrm{S}$ & $\mathrm{O}$ & $\mathrm{N}$ & $\mathrm{D}$ & $\mathrm{J}$ & $\mathrm{F}$ & M & A & M & $\mathrm{J}$ \\
\hline Coffee sole & 121.52 & 129.30 & 139.33 & 165.33 & 191.00 & 197.33 & 202.00 & 209.20 & 213.31 & 217.16 \\
\hline Coffee/rice & 120.88 & 130.42 & 143.67 & 187.67 & 193.67 & 205.67 & 209.01 & 212.01 & 219.67 & 225.42 \\
\hline Coffee/plantain & 126.23 & 133.65 & 149.00 & 198.00 & 210.33 & 221.67 & 229.34 & 235.35 & 243.65 & 248.93 \\
\hline Coffee/rice/plantain & 122.23 & 126.35 & 131.67 & 257.67 & 274.67 & 287.33 & 192.0 & 196.46 & 198.00 & 201.20 \\
\hline Mean & 122.71 & 129.93 & 140.92 & 177.17 & 192.42 & 203 & 208.09 & 213.34 & 218.66 & 223.18 \\
\hline $\operatorname{LSD}(\mathrm{P}=0.05)$ & 3.32 & 4.16 & 10.09 & 25.96 & 20.12 & 20.02 & 21.76 & 22.32 & 26.15 & 27.41 \\
\hline
\end{tabular}

Table 5. Average yield of rice and plantain in t/ha on intercrops with coffee.

\begin{tabular}{ccc}
\hline \multirow{2}{*}{ Treatment } & \multicolumn{2}{c}{ Yield t/ha } \\
\cline { 2 - 3 } & Grain & Bunch \\
\hline Sole rice & 2.0 & - \\
Sole plantain & - & 62.0 \\
Coffee/rice & 2.0 & - \\
Coffee/plantain & - & 61.9 \\
Coffee/rice/plantain & 1.9 & 61.5 \\
Mean & 1.97 & 61.80 \\
\hline
\end{tabular}

that there were no deleterious effects of intercropping coffee with rice and plantain at early stage of field establishment. This agreed with earlier work reported on the beneficial effect of intercropping some food crops with coffee, [6,7,9], cocoa, oil palm and kola [1,4,5,10]. In Thailand, Japan, Brazil and Cote'Divore, rice has been successfully grown as cover crop with young coffee, cocoa, citrus and rubber trees [10].

The average yield of rice (grain) and plantain (bunch) is shown in Table 5. The yield obtained in the intercrops were as high as their sole crops. This affirms beneficial effect on food production other than better morphological growth due to intercrops earlier reported as an advantage in intercropping $[2,3,11]$. Therefore, coffee/rice and coffee/plantain intercrops which produced good plant growth and higher food production that reduce problem of food crisis could be recommended to coffee farmers at juvenile stage in Nigeria to boost rice production instead of sole planting of either rice or coffee.

\section{REFERENCES}

[1] Adenikinju, S.A. (1980) Mixcropping cacao and oil palm. Cocoa Research Institute of Nigeria (CRIN) Annual Report, 14.

[2] Okigbo, B.N. and Greenland, D.J. (1975) Intercropping system in tropical Africa. Multiple Cropping, 27, 378.

[3] Okigbo, B.N. (1977) Preliminary cassava intercropping trials. 1st National Cassava Workshop, Umudike.

[4] Ofoli, M.C. and Lucas, E.O. (1988) The performance of oil palm (Elias guinensis Jacq) and some food crops under intercrops system and effects on the soil under factors cassava based croppings system Research II. Second Annual Meeting of the Collaborative Group in Cassava Based Cropping System Research, Ibadan, 7-10 November 1988.

[5] Okpala-Jose, A. and Lucas, E.O. (1989) Performance of live mulch/maize/cassava/oil palm intercropping system 1 . Assessment of the biological yields of the oil palm yield of food crops and economic returns. The International Conference on Oil Palm and Products, Benin City, 21-25 November.

[6] Famaye, A.O. (2005) Evaluation of nutrient uptake in coffee intercropped with maize, cassava and plantain in Nigeria. Nigerian Journal of Applied Science, 23, 1-5.

[7] Famaye, A.O. (2000) Effect of shade regimes on growth 
and nutrient uptake of seedling and matured tree of coffea species in Nigeria. Ph.D. Thesis, University of Ibadan, Nigeria.

[8] Famaye A.O. and Agboola, A.A. (2003) Effect of shade cover on nutrient status of soil under coffee plantation in Nigeria. Nigeria Journal of Science, 37, 35-40.

[9] Okelana, M.A.O. (1982) Rehabilitation of coffee. Cocoa
Research Institute of Nigeria (CRIN) Annual Report, 39.

[10] CTA (1993) Upland rice. The Tropical Agriculturist, Macmillian Press Limited, London and Basingstoke.

[11] Herrera, W.A.T. and Harwood, R.R. (1973) Crop interrelationship in intensive cropping systems (memo paper). IRR Seminar. 